\title{
GOOD CORPORATE GOVERNANCE ON THE EARNINGS MANAGEMENT USING ISO9001 AS A MODERATING VARIABLE IN BANKING INDUSTRY IN INDONESIA
}

\author{
Carina Heurestica Asparagina Paradisea \\ Faculty of economics majoring in accounting, Airlangga University Indonesia \\ carinaparadisea@gmail.com
}

\begin{abstract}
Earnings management is one of the consequences of information asymmetry in agency theory, this is because the manager (agent) knowing more information about the company managed. Earnings management actions produced financial statements that didn't accordance with the actual situation. Good Corporate Governance (GCG) is a mechanism which is expected to create a climate of good governance in controlling earnings management practices. The aim of this study was to determine and analyze the effect of good corporate governance in terms of the composite score which consists of eleven indicators with earnings management using ISO 9001 as a moderating variable. The study sample met the criteria were 13 banking companies listed in Indonesia Stock Exchange during the period of 20082011. The sampling technique used was purposive sampling method, the number of observations was 51. The analytical tool used in this study is the single Linear Regression. Based on the results of the individual tests, showed that GCG had no effect on earnings management and is reinforced with ISO 9001.
\end{abstract}

Keyword: Good Corporate Governance, Earning Management, ISO 9001, and composite score 


\section{Introduction}

Manipulation of financial statements ever conducted by PT Lippo Tbk and PT Kimia Farma in 2001 and then proved that the practice of manipulation of financial statements remains done by the corporate party despite the crisis period away from 1997-1998 Marihot and Setiawan (2007). The practice of financial report manipulation is allegedly due to poor corporate governance, good corporate governance or Good Corporate Governance (GCG) has now been implemented in various industry sectors, including banking industry.

Marihot and Setiawan (2007) explained that GCG is a concept proposed to improve the company's performance through supervision or monitoring of management performance and ensure accountability of management to stakeholders by basing on the regulatory framework, this is aimed at achieving more transparent corporate management for all users of financial statements. The financial statements made by the company with the aim to provide complete information about the economic activities of a company. Companies that have gone public use financial statements as a medium of communication as well as a reference by parties in conflict for decision making. Fairness and transparency in the presentation of financial statements are necessary to meet the information needs of internal and external parties who have the authority to obtain such information. Therefore, the Capital Market Supervisory Agency (Bapepam), which is now managed by the Otoritas Jasa Keuangan (OJK), has rules and requirements for the company in presenting the financial statements.

There are certain rules that must be obeyed by Indonesian banking companies such as policy package in order to support the operationalization of Indonesian Banking Architecture (API) in 2005 which will be fully implemented in 2010 Farida, et al (2010). According to Bank Indonesia Circular Letter no. 15/15 / DPNP / 2013 on the implementation of GCG for commercial banks there are eleven indicators that will be used in this study.

Company performance can be improved through GCG. One measure of corporate performance that is often used as a basis for decision making is the profit generated by Subramanyam (1996), where the profit is measured on an accrual basis. Accrual income is considered a better measure of firm performance than operating cash flows because accrual reduces time and mismatching problems in the use of short-term cash flows (Dechow, 1994 in Subramanyam, 1996). But the ever-expanding flexibility in the implementation of Generally Accepted Accounting Principles allows management to choose accounting policies from various policy options, so in turn, this flexibility allows for earnings management (EM) by corporate management Subramanyam (1996).

Companies that separate management and ownership functions are more susceptible to agency conflict. This happens because managers who serve as managers of automated companies know more about the company's position, internal information and future prospects than shareholders. Bank Indonesia with Commercial Bank is a form of relationship between principal and agent that cannot avoid conflict or difference of interest Farida, et al (2010).

GCG mechanisms can minimize the behavior of EM managers. GCG is a set of mechanisms used to limit the emergence of information asymmetry problems that can lead to EM (Darmawati Deni, 2003 in Welvin, I., and Arleen, H, 2010).

Seeing the importance of GCG in minimizing the EM action to make GCG and eleven indicators that influence it can be used as research objects. The authors are 
interested in conducting further research to see whether GCG implementation mechanisms in accordance with Bank Indonesia regulations can minimize EM actions that occur in the banking industry in Indonesia.

Adoption of good GCG in accordance with established procedures can affect the quality of products or services of companies, in particular, the banking industry. The quality which is the output of quality management is said to have met the international requirements when the company gets certificate Organization Internationale de normalization (ISO). ISO 9001 is an international standard in the field of quality management systems. ISO 9001 owned by the company is expected to minimize earnings management action. So the purpose of this study is that ISO 9001 as a moderating variable can strengthen GCG in minimizing EM action.

\section{Literature Review}

Sumaedi Sik \& Medi Yarmen (2015) aims to propose an instrument that can be used to measure the effectiveness of ISO 9001 implementation in food manufacturing. This research is considered important because with the ISO 9001 measurement instrument required by food manufacturing companies can measure and improve the standard of the company's quality management system.

Wang Chun-Hsien (2014) examines the relationship between innovation capability and quality management initiatives and considers how quality management initiatives affect the ability to innovate and firm performance. Quality management certification moderates positively the relationship between innovation capability and company performance.

Man Chi-keung \& Brossa Wong (2013), this study aims to examine the effect of GCG in reducing or even eliminating EM levels. Typically, institutional environments that provide better legal protection can control the interests of managers to some extent. The takeover of authority can lead to pressure on the market and managers can do the best for shareholders. The independence of the board can monitor the improvement of manager behavior, including asset abuse. The audit committee may oversee the internal controls for financial reporting and the quality of financial information. Directors with financial expertise can provide the incremental effect of EM control, especially in companies with weak business governance.

\section{Agency Theory}

Agency theory explains the agency relationships that occur when one or more people (agents) employ other people (agent) to provide a service and then delegate decision-making authority to the agent Jensen and Mecking (1976). The agency theory is the basis used to understand GCG and the contractual relationship between members in the company. The principal is a shareholder or investor while the agent is the management that manages the company. The essence of the agency relationship is the separation of functions between ownership in investors and controls on the part of management.

The existence of separation of authority between the owner of the company (principal) and the manager by the management (agent) tends to lead to agency conflicts between principals and agents. Conflicts of interest between owner and agent occur because the possibility of the agent does not always do in accordance with the wishes of the principal, thereby causing agency costs (agency cost) 
Ujiyantho and Pramuka (2007). Agency cost is the cost incurred by the principal for the cost of oversight of the agent, the binding expenditure by the agent, and the residual loss of Jensen and Meckling (1976). The residual loss is, the value of money arising from the existence of irregularities between the decisions taken by the agent and the decision that will improve the welfare of the principal so as to cause losses or reduction of the welfare of principals Jensen and Meckling (1976).

Principals who cannot always monitor management activities to ascertain whether management has worked in accordance with the wishes of the principal may result in a conflict of interest. Sometimes the information submitted does not match the actual company condition. Such a condition is known as asymmetric information Wibisono (2004).

The existence of such information asymmetry may prompt the agent to hide some unknown information of the principal to maximize profit for the agent. Agencies can be motivated to report non-actual information to the principal, especially if the information relates to the performance measurement of the agent Ujiantho (2007).

\section{Good Corporate Governance}

According to Effendi (2009: 2) understanding, GCG is a set of systems that regulate and control the company to create value added (value added) for the stakeholders. GCG can encourage the formation of Clean, Transparent, and Professional management (BTP). The World Bank defines GCG as a compilation of laws, regulations, and rules that can encourage the performance of corporate resources to function efficiently to generate long-term, sustainable economic value for shareholders and the surrounding community Overall Effendi (2009).

The purpose of issuance of Bank Indonesia Regulation (PBI) no. 8/4 / PBI / 2006 on GCG implementation for Commercial Banks is to strengthen the internal condition of the national banking system in accordance with the Indonesian Banking Architecture (API) in the face of increasingly complex risks, improve Bank performance, protect the interests of stakeholders, and improve compliance prevailing laws and regulations and ethics values that are generally accepted in the banking industry. Implementation of GCG in the banking industry should always be based on 5 (five) basic principles as follows:

1. Transparency is openness in expressing material and relevant information and openness in executing decision process;

2. Accountability is the clarity of the function and implementation of the Bank's organ liability so that its management runs effectively;

3. Responsibility is the suitability of Bank management with applicable laws and regulations and sound bank management principles;

4. Independence is the professional management of the Bank without the influence/pressure of any party; and

5. Fairness which is justice and equality in fulfilling the rights of stakeholders arising based on the agreement and the prevailing laws and regulations.

$\mathrm{PBI}$ explains that in order to implement these five basic principles, the Bank shall be guided by various minimum provisions and requirements as well as guidelines related to the implementation of GCG. Based on Circular Letter to All Conventional Commercial Banks in Indonesia on 29 April 2013, the Bank shall conduct a periodic self-assessment which shall at least cover 11 (eleven) GCG Implementation Assessment Factors, namely: 
1. The duties and responsibilities of the Board of Commissioners are the number, composition, criteria, and independence of the members of the Board of Commissioners, duties, and responsibilities of the Board of Commissioners and Board of Directors, and the recommendations of the Board of Commissioners.

2. The execution of duties and responsibilities of the Board of Directors is the number, composition, criteria, and independence of the members of the Board of Directors of the duties and responsibilities of the Board of Directors; and recommendations of the Board of Commissioners.

3. the completeness and execution of the duties of the Committees shall be the structure, membership, expertise, and independence of Committee members, duties and responsibilities of the Committee, the frequency of meetings of the Committee, and the work program of the Committee and its realization.

4. Handling of conflict of interest from other information related to GCG Bank in the form of owner's intervention, internal disputes, or issues arising from the impact of remuneration policy on the Bank.

5. Implementation of compliance function consists of the Bank's compliance level with respect to all applicable laws and regulations as well as the fulfillment of commitments with the competent authority.

6. The implementation of the internal audit function consists of the effectiveness and scope of the internal audit in assessing all aspects and elements of the Bank's activities.

7. The implementation of the external audit function consists of the effectiveness of external audit implementation and the Bank's compliance with the provisions concerning:

1) Relationship between Banks, Public Accountants, and Bank Indonesia for Conventional Banks; or

2) The relationship between Sharia Banks, Public Accounting Firm, Public Accountant, Sharia Supervisory Board and Bank Indonesia for Sharia Banks, as stipulated in the Bank Indonesia provisions concerning Transparency of Bank Financial Condition.

8. Implementation of risk management including the internal control system. The information that needs to be disclosed is the active supervision of the Board of Commissioners and the Board of Directors, the adequacy of policies, procedures and the determination of limits, the adequacy of the process of identification, measurement, monitoring and risk control and risk management information system, and comprehensive internal control system.

9. Provision of funds to related parties and large exposure. The information that needs to be disclosed is the total amount of the debit of the provision of funds to related parties and the core debtor/group per report position.

10. Transparency of the Bank's financial and non-financial conditions that have not been disclosed in other reports; and

11. The Bank's strategic plan includes:

a. Corporate plan; and

b. Medium and short-term plan (business plan).

The sum of the values of the eleven indicators is called the composite value, the composite value is composed of five, that is a very good value if the composite value is less than 1.5, the assessment is measured less than equal to 1.5 to 2.5 , the appraisal is quite good when the composite value less than equal to 2.5 to 3.5 , the assessment is less well measured less than equal to 3.5 to 4.5 , the assessment is not good if the value of composite value is less than equal to 4.5 to less than 5 . 
While the health rating Bank in Bank Indonesia Circular Letter no. 13/24 / DPNP / 2011 is divided into five categories: 1 (low), 2nd (low to moderate), 3rd (moderate), 4th (moderate to high) and 5 (high), a rating then the Bank is said to be healthy and composite value will be good also.

\section{Earning Management}

Setiawati and Na'im (2000) define EM as management intervention in the external financial reporting process in order to benefit itself. Factors that can reduce the credibility of financial statements are EM. EM adds to the bias in the financial statements and can disrupt the use of financial statements that believe the engineering profit figure as an unprofessional profit figure. EM firms are the actions of managers to engineer earnings in accordance with the expected earnings by the management. In general, EM can be divided into two categories, namely EM through accounting policies and EM through real activity. EM using accounting policy refers to a game of profit figures conducted using accounting techniques and policies. Meanwhile, real EM is done through a game of profit made through activities derived from normal business activities or related to operational activities.

Deddy, et al (2011: 40) explains that EM can be done by enlarging or decreasing earnings and can also do income smoothing or income smoothing. (Scott, 2000 in Kusindratno and Sumarta, 2005) explains that there are four EM patterns, namely:

(1) Taking a bath. This pattern is done by arranging the company's earnings of the current year to be very high or low compared to the profit of the previous year or the following year. This is done when unfavorable bad circumstances cannot be avoided in the current period, by writing off certain assets and recognizing costs in future periods and current period losses, in order to obtain performance that both in the future when economic conditions are more profitable.

(2) Income minimization. This pattern is done by making the profit period of the current year is lower than the actual profit. This is done when the company gains high profitability with the aim of not getting attention politically and because of the motivation of taxation. Policies taken can include the loading of advertising expenditure, research and development are fast and so on. This method is similar to taking a bath but less extreme.

(3) Income maximization. This pattern is done by making the income of the current year more long than the actual profit by using several kinds of techniques. This is done with the intention to maximize profits in order to obtain a larger bonus. Similarly, with a company approaching a breach of long-term debt contract, the manager of the company will tend to maximize earnings. Usually managers in performing the act of income maximization using how to delay reporting the cost of the period of the current year to the next period, with the selection of accounting methods that can maximize profit to increase the number of production and sales.

(4) Income smoothing. This pattern is done through income smoothing by increasing or decreasing the profit to reduce the reported profit fluctuations so that the company looks stable and not high risk. Investors and creditors who have risk adverse nature, consider the stability of profit is important in decision making because the more the company's profit fluctuates, then the company can be said to be at risk.

According to Deddy, et al, 2011 and Scott, 2000 in Wedari (2004), there are several motivation managers in EM, namely: 
a) Bonus Plan (bonus scheme). This motivation is done when the condition of the manager wants to get the bonus that comes from the shareholders based on the evaluation of the performance of managers in running the company's operations. Managers with bonus plans will avoid accounting methods that may report lower net income. Managers use accounting earnings to determine a number of bonuses, it is likely to be done manager to choose accounting policies that can maximize profit.

b) Taxation Motivation (taxation motivation). Motivation taxation is the most real EM motivation because every company wants to minimize the profit so that the tax paid is also minimal. For example, the ways in which such as change the method of recording inventory to LIFO for the resulting net profit is low.

c) Debt Covenant Motivation. The motivation of debt agreements is the motivation of managers to be able to shrink profits due to the reason to fulfill the debt agreement arising from long-term debt contract. Managers will tend to choose accounting methods that can "move" future period earnings into the current period so as to reduce the likelihood of a company experiencing a breach of contract.

d) The motivation of Sale of Shares. This motivation is used by companies that will go public or who have gone public. The company wishes to acquire venture capital from investors by selling its shares, so the manager will do EM by showing a large profit for investors interested in buying the company's shares. This information can be used as a signal to potential investors about the value of the company.

e) The motivation of Substitution of the Board of Directors. EM practice usually takes place around the turnover period of the board, it is because as the term of office expires, the directors tend to maximize profits to look good at the end of their tenure. This motivation aims to obtain maximum bonus at the end of his tenure.

f) Political Motivation. Managers tend to present lower returns than they actually are, doing so in order to lessen the visibility of a company so as not to attract the attention of governments, media or consumers that can lead to increased political costs because of low political costs can benefit the management. This action is done to obtain facilities and facilities from the government such as subsidies.

The detection of EM behavior within the firm can be done by means of total accrual measurement. According to Djakman (2003), EM action can be done through the accrual policy. To understand what is meant by the accrual policy, here is a citation of the definition of the accrual policy of the Financial Accounting Standard Board (FASB, 1978):

"Accrual accounting attempts to record the financial effects on an entity of transactions and other events and circumstances the have cash consequences for the entity in the periods in which those transactions, events, and circumstances occur rather than only in the periods in which cash is received or paid by the entity".

Total accrual is the difference in profit and cash flows from operating activities. The total accrual measurement can be divided into two, namely discretionary accruals and nondiscretionary accruals. According to Yang, et al, (2009) states:

"The magnitude of discretionary accruals is indicated as a percentage of assets of a firm. The higher the value of discretional accruals, the greater the earnings are manipulated. Earnings management may take the form of either income-increasing or income-decreasing accounting choices.income-increasing manipulation means positive discretionary accruals whereas income-decreasing indicate negative discretionary accruals". 
Based on the above statement can be concluded that a number of discretionary accruals can be indicated as a percentage of the company's assets. The higher the value of discretionary accruals, the greater the profit being manipulated. EM can be an accounting choice with increasing or decreasing profit calculations. Increased earnings mean the manipulation of positive discretionary accruals while decreasing income indicates a negative discretionary accrual.

Welvin and Arleen (2010) describe discretionary accruals as an accrual component that allows managers to intervene in the process of preparing financial statements so that profits reported in the financial statements do not reflect the true value or condition of the enterprise. Discretionary accruals include among others the valuation of receivables, the recognition of warranty expenses, and capitalization assets. While the nondiscretionary accruals component is determined by other factors that are not supervised by the manager.

\section{ISO 9001}

Nasution (2001) states that quality management is a combination of all management functions, all parts of a company and everyone into a holistic philosophy built on the concept of quality, teamwork, productivity, and customer satisfaction. According to the National Standardization Agency (bsn.go.id, 2011), there are 4 (four) important elements must be met in order to implement the implementation Quality Management System (QMS) ISO 9001: 2008, namely: Management system quality, management responsibilities, resource management, product realization, as well as measurement, analysis, and improvement. In every implementation, companies must have QMS documents because the QMS document is instrumented / references to carrying out all activities in order to be controlled, may monitor, evaluated in an effort to improve/improve quality sustainably. It is also supported by the existence of the quality policy, quality objectives, quality audits, internal audits and management reviews.

In ISO 9001: 2008 the company must have several stages the process to the successful implementation of ISO 9001: 2008, then set 8 (eight) principles of quality management according to Djatmiko (2011), namely:

1. Customer focus,

2. Leadership,

3. The involvement of personnel,

4. Process approach,

5. System approach to management,

6. Continuous improvement,

7. Factual approach as the basis for decision making, and

8. Relationships with mutually beneficial suppliers.

The benefits of applying ISO 9001: 2008 (QMS) have been obtained many companies according to Djatmiko (2011) are:

1. Improve customer trust,

2. Quality assurance of products and processes,

3. Increase company productivity and market gain,

4. Increase employee motivation, morale, and performance,

5. As a tool of competition analysis company,

6. Improve mutual relationships with suppliers,

7. Increase cost efficiency and product safety,

8. Increase internal communication, 
9. Improve the company's positive image,

10. Documented system, and

11. Media for training and education.

\section{Good Corporate Governance Relation to Earning Management}

GCG mechanism requires a concrete form of a report that can describe the condition of the company and also as a form of management accountability to shareholders. Based on this report, it can be seen whether the performance of the company has good governance and effective GCG and from the governance whether it can reduce the opportunistic behavior of management in the company such as EM activities. This report is in the form of financial statements. A company that embraces GCG, will surely prioritize transparency in its financial reporting from the manager to shareholders, as well as to the public. Dody Hapsoro, 2006 in Indri (2011) states that the goodness of GCG should be seen from the dimensions of transparency. Transparency can be seen in the very detailed financial statements on the record so that the public can find out the sources of funds and expenses made by the company. Transparency will prove whether opportunistic management behavior occurs or not to prove good corporate governance whether or not.

H1: Good Corporate Governance affects Earnings Management

\section{Good Corporate Governance Relation to Earning Management and ISO 9001 as Moderating Variables}

The quality management system will be recognized internationally if a company has obtained ISO 9001 certificate. The implementation of ISO 9001 will have a major impact on the organization as it can be one way to survive and develop in difficult situations because the quality of the products or services produced has been standardized internationally and equal to the standards possessed by the developed countries of the world. The existence of quality assurance from ISO 9001 certificate in collaboration with good GCG is expected to minimize EM action.

$\mathrm{H} 2$ : The quality management certification moderates positively the relationship between Good Corporate Governance and Earnings Management

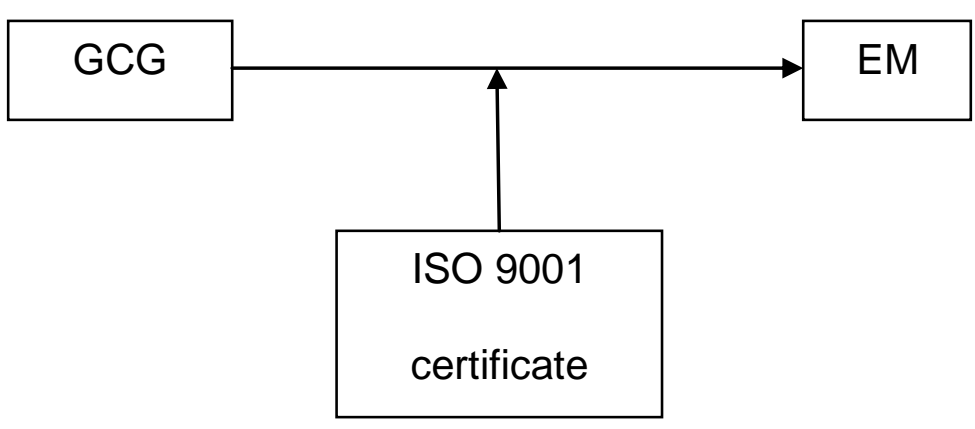

Figure1: Framework for Thinking 


\section{Methodology}

The population to be used in this research is all national commercial banks in Indonesia, while the sample in this study is all national commercial banks in Indonesia which publish annual reports and GCG reports in 2008-2011. Determination of the sample is done by purposive sampling that meets the qualification as the object of research that has been determined by the researcher to be relevant to the purpose of the research, with the following criteria:

1. National commercial banks in Indonesia that regularly publish GCG reports in 2008-2011.

2. National commercial banks in Indonesia that routinely publish annual reports in 2003-2012.

The independent variable used is GCG bank. The GCG of the bank is assessed by eleven factors, namely the implementation of the duties and responsibilities of the Board of Commissioners, the implementation of the duties and responsibilities of the Board of Directors, the completeness and performance of the Committee's duties, the handling of the conflict of interests, the implementation of the compliance function, the application of the internal audit function, the implementation of the external audit function, internal control system, provision of funds to related parties and large exposures, transparency of financial and non financial condition of Bank GCG implementation report and internal reporting and strategic plan of the Bank. The GCG assessment in this study is reflected in the composite values contained in the GCG report. The composite value is the sum of the weights with the ratings contained in the self-assessment tables of each Bank which can also show how well a bank executes corporate governance or GCG.

$E M$ is the dependent variable to be studied in this study. Beaver and Engel Model (1996) states that in detecting EM using an accrual model. Where the use of the allowance for loan losses component and the provision for loan losses as a component of total accrual form in the banking company. The Beaver and Engel model (1996) is written as follows:

$$
\mathrm{TA}_{\mathrm{it}}=\alpha o+\alpha_{1} C O_{\mathrm{it}}+\alpha_{2} L O A N_{\mathrm{it}}+\alpha_{3} N P A_{\mathrm{it}}+\alpha_{4} \Delta N P A_{\mathrm{it}+1}+\varepsilon_{\mathrm{it}}
$$

$T A_{i t}$ is the total accrual to know the total accrual is to use the balance of productive removal allowance (PPAP) and to obtain the total accrual coefficient of all earnings management variables, among which Coit (Loans charge-offs or credit removed book), LOAN it (Outstanding Loans), $N P A_{i t}$ (Non Performing asset), and $\triangle N P A_{i t+1}$ (non-performing asset in the next year with non performing asset $t$ ) is first determined by book value of equity and loan loss reserve (gross value).

$$
\mathrm{NDA}_{\mathrm{it}}=\mathrm{TA}_{\mathrm{it}}-\left(\alpha o+\alpha_{1} C O_{\mathrm{it}}+\alpha_{2} L O A N_{\mathrm{it}}+\alpha_{3} N P A_{\mathrm{it}}+\alpha_{4} \Delta N P A_{\mathrm{it}+1}\right)
$$

$T A_{i t}$ is the total accrual (balance of PPAP) of bank $\mathrm{i}$ in year $\mathrm{t}, N D A_{i t}$ is the accrual of bank $\mathrm{i}$ in year $\mathrm{t}, \mathrm{Co}_{\text {it }}$ is loan change offs (loan removed book), LOAN it is loaned outstanding, $N P A_{i t}$ Non performing asset (problematic earning assets), consisting of level-based earning assets its collectibility which can be classified into three parts, namely: substandard (KL), doubtful (D), and jammed (M), and $N P A_{i t+1}$ Difference in non-performing assets $t+1$ with non performing asset $t$.

$$
\text { DA }_{\text {it }}=\mathbf{T A}_{\text {it }}-\mathbf{N D A}_{\text {it }}
$$

$\mathrm{Da}_{i t}$ is accrual bank managed $\mathrm{i}$ in year $\mathrm{t}, T a_{i t}$ is total accrual (for accrual total accruals) is calculated based on total allowance for possible losses on assets earning (PPAP) bank $\mathrm{i}$ in year $\mathrm{t}$, and NDAit is non-bankable accrued bank $\mathrm{i}$ in year $\mathrm{t}$. 
ISO 9001 certification is a moderating variable whose value is obtained from viewing the bank's financial statement whether the bank has been certified or not.

\section{Findings/Discussion}

This study uses regression model, namely: $Y=\alpha+\beta 1 G C G+\varepsilon 1$ which is used to test the effect of GCG on EM, and $Y=\alpha+\beta 1$ GCG $1+\beta 2$ ISO $2+\beta 3$ GCG 1ISO2 $+\varepsilon$.

Table 1

Selection Result Of Samples

\begin{tabular}{|c|c|c|c|}
\hline No & Information & Amount & Accumulation \\
\hline 1 & $\begin{array}{l}\text { Banking companies listed on the Indonesia Stock } \\
\text { Exchange in } 4 \text { years of the study period (2008- } \\
\text { 2011). }\end{array}$ & $\begin{array}{l}36 \text { bank } \times 4 \\
\text { year }\end{array}$ & 144 \\
\hline 2 & $\begin{array}{l}\text { Data eliminated: } \\
\text { 1. The banking company does not publish or } \\
\text { submit a Good Corporate Governance (GCG) } \\
\text { report in full or does not include composite } \\
\text { value. ( } 21 \text { banks } \times 4 \text { years) } \\
\text { 2. The company does not have complete data } \\
\text { available to detect EM. ( } 2 \text { banks } \times 4 \text { years) }\end{array}$ & $\begin{array}{l}\text { (84) } \\
\text { (8) }\end{array}$ & \\
\hline \multicolumn{3}{|c|}{ Total data 4 years study period } & $\begin{array}{c}52 \text { Data / } 13 \text { Banking } \\
\text { Companies }\end{array}$ \\
\hline
\end{tabular}

Source: idx.co.id, secondary data that has been processed.

Table 2

Descriptive Statistical Analysis Of Independent Variables Good Corporate Governance

\begin{tabular}{|l|r|r|r|r|r|}
\hline \multicolumn{7}{|c|}{ Descriptive Statistics } \\
\hline GCG & N & Minimum & Maximum & Mean & Std. Deviation \\
Valid N (listwise) & 52 & 1,00 & 2,68 & 1,5391 &, 42668 \\
\hline
\end{tabular}

Source: Appendix 1, processed

The standard deviation (SD) shown in the above table is worth 0.42668 which means that the value is less than one so that the variation of the data value is getting the same, the value can also reflect the average value of data deviation with the average value 1.5391 , so it can be known that the Mean value can be used as a representation of the whole data because the $S D$ value is very small compared to the Mean value.

Table 3

Descriptive Statistics Analysis Of Dependen Variables

Earning Management

Descriptive Statistics

\begin{tabular}{|l|r|r|r|r|r|}
\hline & $\mathrm{N}$ & \multicolumn{1}{|c|}{ Minimum } & Maximum & \multicolumn{1}{|c|}{ Mean } & Std. Deviation \\
\hline EM & 52 &, 02 & 1,08 &, 1548 &, 14728 \\
Valid N (listwise) & 52 & & & & \\
\hline
\end{tabular}

Source: Appendix 2, processed 
The average value of EM seen through discretionary accruals is 0.15 , based on the above data it can be seen that the mean value is greater than the SD. Although the range of values of the two is not too far away it can show that Mean represents data well.

Table 4

Descriptive Statistics Analysis Of Moderating Variables

ISO 9001

\begin{tabular}{|l|r|r|r|r|r|}
\hline & Descriptive Statistics \\
\hline ISO_9001 & Minimum & Maximum & Mean & Std. Deviation \\
Valid N (listwise) & 52 &, 0 & 1,0 &, 692 &, 4660 \\
\hline
\end{tabular}

Source: Appendix 3, processed

The average value of EM seen through discretionary accruals is 0.69 , based on the above data it can be seen that the mean value is greater than the SD. Although the range of values of the two is not too far away it can show that Mean represents data well.

Table 5

Normality Test

One-Sample Kolmogorov-Smirnov Test

\begin{tabular}{|c|c|c|}
\hline & & Unstandardized Residual \\
\hline $\mathrm{N}$ & & 52 \\
\hline Normal Parameters ${ }^{a, b}$ & Mean & 0E-7 \\
\hline & Std. Deviation & 05943567 \\
\hline & Absolute & ,090 \\
\hline Most Extreme Differences & $\begin{array}{l}\text { Positive } \\
\text { Negative }\end{array}$ & $\begin{array}{r}, 090 \\
-, 086\end{array}$ \\
\hline Kolmogorov-Smirnov Z & & ,648 \\
\hline Asymp. Sig. (2-tailed) & & ,795 \\
\hline
\end{tabular}

a. Test distribution is Normal.

b. Calculated from data.

Source: Appendix 4, processed

Kolmogorov-Smirnov is 0,648 with Asymp.Sig (2-tailed) that is equal to 0.795 . This value is greater than the significant coefficient of $0.005(0.795>0.005)$ which means the residual of the above regression model can be concluded that the data is normally distributed and can be used to predict or forecast the value of the dependent variable EM (Y).

Table 6

Result Of Regression Analysis

Coefficients

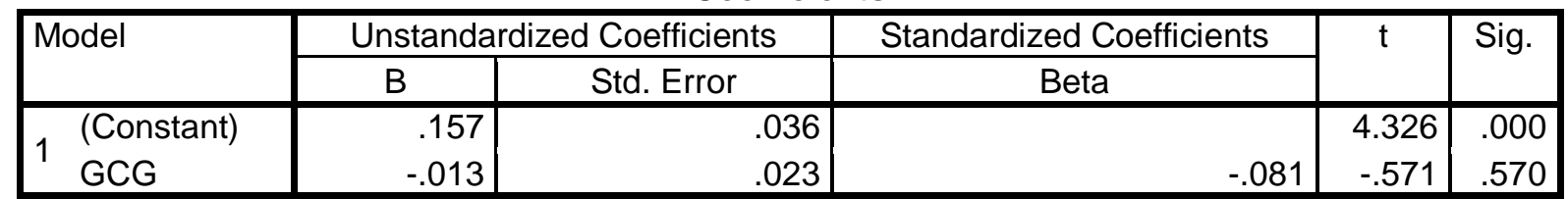

a. Dependent Variable: EM

Source: Appendix 5, processed

Based on table 6 above, the regression equation is not obtained because the GCG variable has no effect on the proven EM variable of GCG significant value of 0.570 which means greater than 0.05 . 
Test R2 is used to measure how far the model's ability to explain the variant variables of a variable. The value of the coefficient of determination (R2) is between zero and one, the small value of $\mathrm{R} 2$ means that the ability of the independent variables in explaining the dependent variable is very limited. Here are the simple regression results for the calculation of the coefficient of determination:

Table 7

First Determination Coefficient Analysis Results

Model Summary

\begin{tabular}{|c|c|c|c|c|c|c|c|c|c|}
\hline \multirow[t]{2}{*}{ Model } & \multirow[t]{2}{*}{$\mathrm{R}$} & \multirow{2}{*}{$\begin{array}{c}\mathrm{R} \\
\text { Square }\end{array}$} & \multirow{2}{*}{$\begin{array}{l}\text { Adjusted R } \\
\text { Square }\end{array}$} & \multirow{2}{*}{$\begin{array}{c}\text { Std. Error of the } \\
\text { Estimate }\end{array}$} & \multicolumn{5}{|c|}{ Change Statistics } \\
\hline & & & & & $\begin{array}{c}\text { R Square } \\
\text { Change }\end{array}$ & $\begin{array}{c}\mathrm{F} \\
\text { Change }\end{array}$ & df1 & df2 & $\begin{array}{c}\text { Sig. F } \\
\text { Change }\end{array}$ \\
\hline 1 &, $131^{\mathrm{a}}$ & ,017 &,- 002 & ,0629643 & ,017 & ,877 & 1 & 50 & ,354 \\
\hline
\end{tabular}

a. Predictors: (Constant), GCG

b. Dependent Variable: EM

Source: Appendix 6, processed

Table 8

Second Determination Coefficient Analysis Results

Model Summary

\begin{tabular}{|c|c|c|c|c|c|c|c|c|c|}
\hline \multirow[t]{2}{*}{ Model } & \multirow[t]{2}{*}{$\mathrm{R}$} & \multirow{2}{*}{$\begin{array}{c}\mathrm{R} \\
\text { Square }\end{array}$} & \multirow{2}{*}{$\begin{array}{l}\text { Adjusted R } \\
\text { Square }\end{array}$} & \multirow{2}{*}{$\begin{array}{l}\text { Std. Error of the } \\
\text { Estimate }\end{array}$} & \multicolumn{5}{|c|}{ Change Statistics } \\
\hline & & & & & $\begin{array}{l}\text { R Square } \\
\text { Change }\end{array}$ & $\begin{array}{c}\mathrm{F} \\
\text { Change }\end{array}$ & df1 & df2 & $\begin{array}{l}\text { Sig. F } \\
\text { Change }\end{array}$ \\
\hline 1 & $348^{a}$ & ,121 & ,066 & ,0607622 & ,121 & 2,210 & 3 & 48 & ,099 \\
\hline
\end{tabular}

a. Predictors: (Constant), GCG_ISO_9001, GCG, ISO_9001

b. Dependent Variable: EM

Source: Appendix 7, processed

The value of R2 in the first regression is 0.017 or $1 \%$, whereas after the second regression equation the $\mathrm{R} 2$ value rises to 0.121 or $12 \%$. by looking at the above results it can be concluded that the existence of ISO 9001 certification as a moderating variable strengthens the GCG relationship to EM.

Table 9

Test Analysis Result $\mathrm{t}$

Coefficients

\begin{tabular}{|c|c|c|c|c|c|}
\hline \multirow[t]{2}{*}{ Model } & \multicolumn{2}{|c|}{$\begin{array}{c}\text { Unstandardized } \\
\text { Coefficients }\end{array}$} & $\begin{array}{l}\text { Standardized } \\
\text { Coefficients }\end{array}$ & \multirow[t]{2}{*}{$t$} & \multirow[t]{2}{*}{ Sig. } \\
\hline & $B$ & Std. Error & Beta & & \\
\hline $\begin{array}{ll}1 & \text { (Constant) } \\
\text { GCG }\end{array}$ & $\begin{array}{r}.157 \\
-.013\end{array}$ & $\begin{array}{l}.036 \\
.023\end{array}$ & -.081 & $\begin{array}{l}4.326 \\
-.571\end{array}$ & $\begin{array}{l}.000 \\
.570\end{array}$ \\
\hline
\end{tabular}

a. Dependent Variable: EM

Source: Appendix 8, processed

Looking at the table above we can see the effect of independent variables on the dependent variable, at a significance level of $0.05(5 \%)$. So in the table above looks GCG variables have a significance above $0.05(0,570>0,05)$. So based on the 
hypothesis made previously stated $\mathrm{H} 0$ accepted and $\mathrm{H} 1$ rejected which means the company's GCG variable has no partial influence on the EM variable.

The statement does not support the existing theory that GCG is expected to minimize EM action. The results of this study also do not support the statement of Effendi (2009) which states that GCG is a set of systems that regulate and control the company to create value added for the stakeholders. GCG can encourage the formation of Clean, Transparent and Professional management (BTP) management pattern or it can be said that with good GCG system it can minimize EM action.

\section{Conclusion/Implications}

This study aims to examine the effect of GCG on EM with ISO 9001 certificate as a moderating variable in conventional banking companies listed on Indonesia Stock Exchange during the study period 2008 to 2011 which publishes financial reports and annual reports and discloses GCG.

The advantage of this research is that this research is the first research that uses ISO 9001 certificate as moderating variable in researching the influence between GCG and EM. ISO 9001 in this study also first appeared as the view that internationally recognized quality management certificates after obtaining ISO 9001 can be taken into consideration in minimizing EM practice. There are four Banks that are eliminated and used as outlier data such as Bank QNB Kesawan, Bank Swadesi or Bank of India Indonesia, Bank Artha Graha International and Bank Pan Indonesia due to not being ISO 9001 certified. 


\section{References}

Chi-keung Man \& Brossa Wong. 2013. "Corporate Governance And Earnings Management: A Survey Of Literature". The Journal of Applied Business Research. (March/April) 2013. Volume 29, Number 2. Pp 391- 418

Chun-Hsien Wang. 2014. A longitudinal study of innovation competence and quality management on firm performance. Innovation: Management, policy \& practice. 16(3): Pp392 - 403

Deddy Sulistiawan, Yeni Januarsih dan Liza Alvia. 2011. Creative Accounting "Mengungkap Manajemen Laba dan Skandal Akuntansi". Jakarta : Salemba Empat.

Djakman, C. D. 2003. "Manajemen Laba dan Pengaruh Kebijakan Multipapan Bursa Efek Jakarta". Simposium Nasional Akuntansi VI. (Oktober). Pp. 141-162.

Djatmiko, Budi dan Jumaedi. 2011. Simulasi Bisnis Sistem Manajemen Mutu ISO 9001. STEMBI - Bandung Business School, Bandung.

Effendi, Muh. Arief. 2009. "The Power of Good Corporate Governance Teori dan Implementasi”. Jakarta : Salemba Empat

Farida, Yusriati Nur Yuli Prasetyo dan Eliada Herwiyanti, 2010, Pengaruh Penerapan Corporate Governance Terhadap Timbulnya Earning Management Dalam Menilai Kinerja Keuangan Pada Perusahaan Perbankan di Indonesia, Jurnal Bisnis dan Akuntansi. Vol. 12 No. 2. Pp. 69-80

FASB (Financial Accounting Standards Board). 1978. Statement of Financial Accounting Standard No. 1, FASB; USA.

ISO. Implementation Guidance for ISO 9001:2008. Document: ISO/TC 176/SC 2/N 836. Geneva: ISO; 2008

Jensen, Michael C. dan W.H. Meckling. 1976. "Theory of The Firm: Managerial Behavior, Agency Cost and Ownership Structure." Journal of Financial Economics, Vol. 3. Pp 305-360

Kusindratno, R. \& Sumarta, N. H. 2005, Studi Mengenai Indikasi Manajemen Laba dalam Laporan Keuangan Perusahaan Publik di Bursa Efek Jakarta, Jurnal Ekonomi Unmer, Vol. 9, No. 1. (Januari). Pp. 206-221.

Marihot, Nasution dan Doddy Setiawan. 2007. "Pengaruh Corporate Governance Terhadap Manajemen Laba Di Industri Perbankan". Simposium Nasional Akuntansi X,IAI, Makasar 2007.

Nasution, M. N., 2001, Manajemen Mutu Terpadu (Total Quality Management), Jakarta: Ghalia Indonesia.

Peraturan Bank Indonesia (PBI) No. 8/4/PBI/2006. Pelaksanaan Good Corporate Governance bagi Bank Umum. Indonesia

Setiawati, L. \& Na'im, A., 2000, Manajemen Laba, Jurnal Ekonomi dan Bisnis Indonesia, Vol.15, No. 4, Pp. 424-441.

Sik Sumaedi and Medi Yarmen. 2015. "The Effectiveness of ISO 9001 Implementation in Food Manufacturing Companies: A Proposed Measurement Instrument". ELSEVIER, Procedia Food Science 3, Pp 436 - 444

Subramanyam, K.R. 1996. The Pricing of Discretionary Accruals. Journal of Accounting and Economics 22, Pp. 249-281.

Surat Edaran Bank Indonesia. 2011. "Surat Edaran Kepada Semua Bank Umum Konvensional Di Indonesia" No. 13/24/DPNP/2011. 25 (Oktober). Jakarta

Ujiantho, Arif Muh. 2007. "Pengaruh Mekanisme Corporate Governance terhadap Manajemen Laba dan Konsekuensi Manajemen Laba Terhadap Kinerja 
Keuangan." Tesis S2 tak diterbitkan, Magister Sains Akuntansi Universitas Diponegoro

Ujiantho, Arif Muh. dan B.A. Pramuka. 2007. "Mekanisme Corporate Governance, Manajemen Laba dan Kinerja Keuangan." Simposium Nasional Akuntansi X, IAI, Makasar 2007

Wedari, L. K. 2004, “Analisis Pengaruh Proporsi Dewan Komisaris dan Keberadaan Komite Audit terhadap Aktivitas Manajemen Laba". Simposium Nasional Akuntansi VII. (Desember), Pp. 963-974.

Welvin, I. dan Arleen, H. 2010. "Pengaruh Mekanisme Good Corporate Governance, Independensi Auditor, Kualitas Audit dan Faktor lainnya terhadap Manajemen Laba". Jurnal Bisnis dan Akuntansi Vol. 12 No. 1

Wibisono, Haris. 2004. "Pengaruh Earnings Management Terhadap Kinerja Di Seputar SEO”. Tesis S2 tak diterbitkan, Magister Sains Akuntansi Universitas Diponegoro

Yang Shi Wong., Chun Loo Sin, and Ramadili Shamsher Mohamad. 2009. "The Effect of Board Structure and Institutional Ownership Structure on Earning Management". Journal of Economics and Management. Pp. 332-353 